\title{
Memories Without Borders? Spanish Courts and the Case for Universal Jurisdiction
}

JOSÉ COLMEIRO

\author{
"Forgetting is full of memory" \\ - Mario Benedetti
}

\section{Introduction}

The field of memory has become a crucial topic of inquiry across academic disciplines and social discourses in recent years. Andreas Huyssen has referred to the widespread 'obsession with memory and fear of forgetting' in our contemporary globalized culture. ${ }^{1}$ The current preoccupation with collective memories across the globe and the parallel proliferation of critical discourses about the social processes of coming to terms with the collective past, appear symptomatic of cultural anxieties resulting from the systemic transformations caused by forces of globalization. I would like to argue that this resurgence of memory in political, cultural and academic discourses in the age of globalization is not a mere coincidence, but is a direct consequence of globalization. As Aleida Assmann and Sebastian Conrad have noted, the traditional spaces, channels and forms of collective memory are being transformed by, and in reaction to, the forces of globalization. ${ }^{2}$ Local and national spaces and processes of remembrance have not disappeared, but the global has now become the central stage for social and political actors, grassroots movements, and judicial activism. That is why it has become necessary, rephrasing Maurice Halbwachs's conceptualization of the 'social frames' of memory, to examine the 'global frames' of memories.

Early in 2010, the news of Spanish 'star judge' Baltasar Garzón being indicted by Spain's High Court made the headlines of news media across the globe, and filled social networks, blogs, and websites of human rights organizations, grassroots groups and civic associations throughout cyberspace. Judge Garzón had started investigations into the human rights violations, atrocities and forced disappearances that occurred during the Spanish Civil War and the years of Franco dictatorship, following international legal principles ratified by Spain which covered 'crimes against humanity', until he was forced to stop by the National High Court. In one of several paradoxical ironies, Garzón had been accused of acting without jurisdiction in a lawsuit filed by far right organizations, including the Spanish fascist 
party, the Falange, which is considered responsible for the largest number of atrocities committed during and after the Civil War.

The overwhelming response in support of Judge Garzón was global, coming from heads of state, dignitaries, Nobel Prize winners, as well as NGOs, HROs and grassroots community groups across the world. The memories of those atrocities did not belong anymore to one single group or nation, but belonged to the larger transnational community. They were 'memories without borders'. In what follows I would like to examine the parallels and connections between the efforts to recover historical memory in post-dictatorial societies, the formation of transnational memories, and perhaps its future convergence in the emergence of universal jurisdiction.

\section{Historical memory and forgetting in post-Franco Spain}

The Spanish Transition from dictatorship to democracy has been often presented in both academic and media discourses as the paradigmatic model of a peaceful, successful transition, and rapid transformation into a modern democracy, as an exemplar for other nations coming out of dictatorial regimes, particularly in Latin America in the 1980s and in Eastern Europe in the 1990s. ${ }^{3}$ The experience of the Spanish Transition, the replacement of a dictatorial regime by a democracy without the violence of a war or revolution, was at the time, in the mid-1970s, practically without precedent in modern history. The other two political transitions taking place simultaneously in Southern Europe, in Portugal and Greece, were characterized by violent radicalization and the use of revolutionary force in the overthrow of the old regimes, through the direct intervention of the military in civil politics. The consolidation of democracy in both instances was delayed. The Spanish model of a peaceful transition negotiated among the political elites was a new strategy, a 'transition through transaction', which resulted in the relatively fast stabilization of the nascent democracy. ${ }^{4}$ At the same time it started a virtually unexplored process of decentralization of the nation-estate and political devolution, with the recognition of the internal multicultural and multilingual historical reality of Spain. These events made the Spanish Transition a successful example, if not a model, or at least an obligatory reference, for other post-dictatorial transitional processes. ${ }^{5}$

In spite of the grand narrative of the Spanish Transition as an overwhelming success story, which in fact has become a foundational myth of Spanish modernity, ${ }^{6}$ there are some shortcomings inherent to the process of Spanish democracy which cultural critics and historians have noted in hindsight, in particular the way of dealing with the past, or perhaps, of not dealing with it. $^{7}$ The politics of memory of the transition has been repeatedly described as the erasure and eradication of historical memory, and the forgetting and silencing of the past. $^{8}$ 
While that perception is based on the official 'pact of forgetting' brokered by the political elites and is in general terms accurate, I would like to raise a few points for consideration of the role of memory during the Transition. One is that we should take into account the asymmetry of memories across the national geography. The atrophy of memory in the national political discourse was parallel to the recovery of historical memory in the peripheries of the nation-state, where local forms of sub-state nationalism relied heavily on a different collective memory. A major component of the recognition of cultural and ethnical difference of the so called 'historical nationalities' and their demands for political rights was historical memory. The emphasis however was not in reparations or backward-looking justice, but in the restoration of pre-civil war local institutions of government, and Statues of Autonomy for Catalonia, Basque Country and Galicia, which had been cut short by Franco's uprising against the Republic.

The second point is that the relationship between memory and forgetting is not a simple either-or phenomenon, since memory always necessarily involves forgetting, and 'forgetting is full of memory', as the Uruguayan writer Mario Benedetti has stated. ${ }^{9}$ As a corollary of that, I would argue that historical memory did not completely evaporate during the Transition; it may have disappeared from the surface of political debates but left noticeable traces and remained operative in other areas on the margins of power. Memory was exiled from institutional political discourse, and displaced to the intellectual and cultural arena. There it found a distinctive space, as attested by the explosion in the early years of the transition 1976-1978 of literature, documentaries and films, and historical and testimonial accounts dealing with the recent past, and the wide public recognition of those works. ${ }^{10}$ The fact that these works became popular best-sellers and box-office hits, receiving the most important literary prizes in Spain, such as the Planeta and Anagrama, indicates that historical memory still resonated strongly with large segments of the Spanish public, no matter what the political elites had decided behind closed doors, and that a significant memory void still needed to be filled.

A third point: As Paloma Aguilar has argued, the memory of the past was not only present but constituted a key factor in the particular development of the Spanish political transition, but as a negative force. ${ }^{11}$ The haunting of the past was behind the calculated policy of not re-opening of old wounds, to avoid the repetition of national confrontation and violence. The fear of destabilization and potential repetition of a civil war conflict acted as deterrents against a direct confrontation with the past, since that past was considered highly divisive. The traumatic memories of the horrors and atrocities of the Civil War were constant reminders of the potential dangers of a violent re-enactment of the past, and influenced the collective 
will against seeing its repetition, and therefore acted as incentive towards a politics of consensus.

If one of the fundamental lessons learned from historical memory is the avoidance of the repetition of the mistakes of the past, it can be argued that the process of the Spanish Transition had learned important lessons from its past, as well as of its neighbours, and therefore we should consider that the memory of the past may have had a more important role in the transitional process than is generally credited.

Also, I would like to add another correction to the standard and official narrative of the exemplary Spanish Transition: although it is generally remembered as a peaceful process, and as the victory of consensus and moderation over confrontation, the first crucial years of political changes took place in a climate of violence and the threat of political involution did not dissipate until the 1980s. These violent challenges to the process came from small minority sectors on both extremes of the political spectrum: those directly associated ideologically with Franco's regime (extreme right terrorist groups and the un-purged military hierarchies), and from extreme left terrorist organizations such as GRAPO and ETA. But violence also often came from the abusive force of the police, and as it would be later revealed, from secret anti-terrorist state terror. ${ }^{12}$ More than 400 individuals died as a result of political violence in the years of the Transition, the majority at the hands of ETA; and more than 60 died in street demonstrations. The official narrative of the Spanish Transition forgets the violence and intensity of conflicts, and the real possibility of a successful coup (several were attempted, most famously the failed attack on Congress in February 23, 1981). ${ }^{13}$ But this violent reality had a profound effect on the way of dealing with the past.

In an effort to make progress with the democratic reform and the stabilization of the new democracy, the political elites, both the regime reformists and the main leaders of the anti-Franco opposition, agreed, to use the discourse of the times, not to 'reopen the old wounds of the past', to 'turn the page', and focus on the task of building the future, in what became known as the collective 'pact of forgetting', or pact of silence about the past.

In this negotiation, a performance of symbolic reconciliation of the elites, everyone conceded: the system reformists accepted the dissolution of the old regime, the full democratization of the state, the legalization of political parties and release of political prisoners. The leftist anti-Franco opposition sacrificed the memory of repression and suffering in its 40-year collective struggle, reversed their long-standing republicanism and accepted the legitimacy of the monarchy and parliamentarian liberalism, in exchange for freedom and democracy. 
As a result, historical memory was institutionally disavowed; it was problematic, messy, dangerous, and did not benefit the principal actors of the emerging democracy. Both sides had skeletons in the closet, and everybody had something to lose. It was not considered appropriate to remember that the majority of the players on the right and centre of the political spectrum, and particularly those of the UCD party in government between 1977 and 1982, had started their careers as part of Franco's last administrations, such as Prime Minister Adolfo Suárez. For the main national parties of the left, the socialists and communists, the past was also inconvenient. Their legalization by the government was the result of a tacit agreement that they would not seek reparations. It was also in their best interest not to revisit the murky political responsibilities for the atrocities committed on the Republican side during the Civil War. They had already paid collectively 40 years of repression and exile. Historical memory became thus a political taboo in Spanish political culture. ${ }^{14}$

The pact not to deal with the crimes of political nature committed during the Spanish Civil War and its aftermath would result in the Amnesty Law of October 1977, by which the newly elected representatives agreed on a general amnesty for all political motivated crimes committed since 1936 (with the only exception of the right wing minority group, Alianza Popular, which refused pardoning the political crimes of the left). It should be remembered, however, that the main expressed goals behind the Amnesty Law approved was to officially pardon all of Franco's opponents - past political prisoners and exiles - and to put an end to the judicial proceedings of those involved in political struggle, and thus to bring closure to the process of repression. Most Spaniards at the time did not realize that, in actuality, the law also included two articles barring the prosecution of all political crimes committed since the Spanish Civil War on Franco's side, including post-war atrocities, forced disappearances, mass killings, and torture, all classified as 'crimes against humanity' by international law. This fact did not receive the attention of the general media, which focused instead on the more pressing issues of the liberation and integration of political prisoners and the process of national reconciliation. ${ }^{15}$ A 1977 editorial from influential daily El País summarized the general consensus: 'A people cannot and must not lack historical memory: but the latter must serve to encourage projects for peaceful future coexistence rather than promote rancour about the past' ${ }^{\prime 6}$ A result of the Amnesty Law was that not only were those crimes never punished, they were not even investigated, and the victims did not receive justice and appropriate reparation (although gradual reparations were subsequently implemented through the years).

While it can be argued that the amnesty policy was effective in stabilizing an emerging and fragile democracy, and perhaps it was an inevitable measure 
in the context of an extremely challenging political and economic climate, in retrospect it is clear that it created a severe ethical deficit. More than a process of active reconciliation, perhaps impossible to achieve at the time given the powerful presence of the old cadres in the military, the repressive forces, and the judicial structures, it was a disavowal of the past and the legal basis for institutional forgetting. In that sense, political amnesty equalled historical amnesia.

But some additional context is required to understand this particular development, since both the internal social pressures and the international environment were looking in a different direction. Although fundamentally a top-down project modelled by political elites, backward-looking justice and accountability were not a high priority in Spanish society as a whole, and were not part of the international climate either. The main social demands in Spain at the time were freedom, democracy, peace, and stability, with the addition of devolution aspirations from the peripheral nationalisms (especially Catalonia, the Basque Country, and Galicia). ${ }^{17}$ The Civil War and the worst atrocities in its aftermath had happened forty years earlier, and the large majority of the Spanish population, 70\%, had had no direct experience of it, but only through indirect inherited memories or 'postmemories' (a concept borrowed from Marianne Hirsch's study of Holocaust victim descendants). ${ }^{18}$ After forty years of severe repression, and the official erasure of conflicting memories of the past, Spanish society was largely depolarized and lacking in historical memory. In essence, there were no channels for public remembering and little collective desire to remember either. ${ }^{19}$ Spanish society embraced the new liberties and the experience of modernity without much interest in remembering the sordid past, on the contrary, it actively tried to disassociate from this past very rapidly. The generational change would set off the emergence of the Movida and its intense live-the-moment, forget-about-the-past attitude, which would be an illustrative result of this phenomenon. It is also not surprising that a key symbolic figure who reappears forcefully in the cultural narratives of the Transition and the Movida years is the transsexual/transvestite, an ambiguous figure who embodies a past that needs to be forgotten, and a present that is constructed as a series of continuous acts of performance. ${ }^{20}$

I should add that although the main factors of transitional processes are internal to the nation, the international historical context can play a very significant role. The international climate in the mid-1970s as a result of Cold War politics had more tolerance for undemocratic regimes, and less interest in persecuting human rights violations. ${ }^{21}$ There was no strong international pressure for accountability, human rights organizations were not fully developed, and the battle against impunity was not a major motivation, as would be the case in the 1980s and 1990s. 
In this climate of collective forgetting, cultural critics have referred to a 'crisis of memory', and different interpretative models have been employed (psychoanalytical, trauma, repression, melancholia, mourning, spectral 'hauntology' of the past). While many Spanish writers, artists and film directors have grappled with these issues in their works, they all point to a large void in the Spanish collective memory. Thousands of victims of Franco's brutal repression remained forgotten, or unknown. To the new generations of Spaniards, Franco was soon just as forgotten and irrelevant as Napoleon, dismissed as inconsequential for the present, and the atrocities committed during and after the Spanish Civil War were largely ignored. Official school programmes and textbooks hardly made any references to the war or the dictatorship, and the Valley of the Fallen, the colossal mausoleum erected by Franco as a war memorial of the victorious side, and constructed with the forced labour of 20,000 Republican political prisoners, is regularly visited by thousands of tourists, unaware of its dark history which is not mentioned by the official guides. This ethical deficit has been summed up by Spanish writer Almudena Grandes: 'The democratic transition was a success from the point of view of institutions because it allowed the most solid democratic period enjoyed by the country. Yet, from a moral point of view, it was not a success because a generation later we Spaniards cannot accept the deficit of that process'. ${ }^{22}$

\section{Transatlantic mirrors and asymmetries}

So can we still talk about a 'model' transition, and its application to other transitional processes? The idea of the model, implanted and replicated in other countries, is highly problematic, and ultimately probably false. The internal dynamics of each country are very different, and there is a general agreement that, although international factors can be significant determinants, it is above all internal factors that determine the process of a democratic transition. Also, all the efforts of 'exporting democracy' have met with relative failure when not huge disaster, as we have witnessed in recent years. So, we should not see the Spanish Transition as a model handbook, but as a reference, from which lessons, both positive and negative, could be learned. Ultimately, rather than the single exemplary model with different applications, it would be potentially more instructive to see a plurality of different national examples and experiences, acting as potential mirrors, where each one of the participants has looked and learned from each other different ways of dealing with the past, in a sort of transatlantic boomerang effect. I would like to point out several transnational connections which would support this theory of mirrors and rebound effects.

Firstly, the disappearance of Franco's regime, which had been if not exactly a model, at least an important reference point for Latin American 
military dictators, from Trujillo in the Dominican Republic to Pinochet in Chile. Seeing the dismantling of the dictatorship and Spain's overall successful transformation into a democratic society was a sign of hope and encouragement for those seeking the return of democracy in Latin American countries. Spain became also a major refuge for many political exiles from the Southern Cone, in a boomerang reversal of the massive Spanish Republican Diaspora after the Civil War. As a result, valuable transnational cultural connections were established, and mutual learning was attained through actions of solidarity, practices of resistance and experiential exchanges about ways of dealing with the past. ${ }^{23}$ Collective memories were shared and new memories were made.

Secondly, the Spanish transition experimented with new political strategies, the route of political reform through peaceful negotiation, rather than violent overthrown or revolutionary action. This would be the general roadmap followed in most Latin American political transition processes, negotiated transitions, where reform by political force was chosen over rupture. This commonality of experience explains the frequent use of a common lexicon: transition, pact, historical memory, and desencanto (disillusionment with unfulfilled dreams and expectations); these are recurring concepts in the historical and cultural narratives of the Spanish and Latin American postdictatorships which indicate the existence of shared memory discourses.

But there are also important differences. The Latin American transitions of the Southern Cone employed new forms of social action, and adopted a new language of human rights, which were initially absent in the Spanish case. In essence, the Latin American transitions introduce new forms of dealing with the past: through the establishment of truth commissions, official reports, and judiciary tribunals to investigate, document, and prosecute the human rights violations of the past (the first was CONADEP in Argentina in 1983). This phenomenon is perhaps the most significant difference with respect to the Spanish Transition. As we have seen, in the Spanish case, there was a significant lack of trials, truth tribunals, and other acts of investigation and retribution in dealing with the past. In sharp contrast, thousands of cases of forced disappearances and other crimes against basic human rights were documented in Argentina, Uruguay, Brazil and Chile, and a few made it into the court system. In many of those cases, however, those early efforts would bring few successes, and, like in Spain, eventually would be excluded from prosecution due to different amnesty decrees passed, and newly enacted Laws of Full Stop and Due Obedience, as a result of the pressures of the military and the changing political climate, such as the presidential pardon by Carlos Menem in Argentina in 1990 (later annulled in 2005, which allowed the successful prosecution of formerly pardoned military personnel). 
There were also new social actors at work in the Latin American transitions thanks to grassroots mobilization, and thus, the important role of human rights organizations, indigenous community movements, and associations of families of victims, such as the Madres de la Plaza de Mayo, a non-partisan political organization that would obtain world-wide recognition and would serve as example for other human rights civic associations in different countries, including Spain.

There was also a new vocabulary: foremost 'desaparecidos' (allegedly first used in Guatemala in 1966, but infamously employed by the Argentinean armed forces, and subsequently adopted by human rights organizations and victim associations). ${ }^{24}$ The concept of desaparecido, or 'forced disappearance', gained wide international acceptance in discussions of human rights, and moving across borders, eventually would be employed retroactively in the Spanish context. Thus, a double time-space displacement occurred, by which a concept of the second part of the twentieth century imported from Latin America is applied retrospectively to events of the first half of the twentieth century in Spain.

Although most scholars agree that it is internal tensions and agents that are of primary importance in transition processes, regional, transnational and international influences also play a role. I would like to underline the different international time-space contexts: the 1970s Cold War and the 1990s post-collapse of the Soviet Bloc, which both carry different international implications and solutions. Spain's closer proximity to other established European democracies and the assistance received from European political institutions, parties, unions, etc., facilitated the peaceful transition, and assisted with the rapid process of political and economical stabilization. The Cold War international setting did not favour accountability measures and human rights efforts. By the mid and late 1980s, the obsolescence of dictatorships was beginning to be widely recognized, as the example of the Iberian transitions had shown. The new international situation, with the crisis and breakdown of the Soviet bloc, and the end of the Cold War, acted as a catalyst to re-open the past (to learn what had happened in Eastern Europe) and this facilitated the human rights efforts. ${ }^{25}$ The war of the Balkans and the genocide in Rwanda in the early 1990s were also major boosts to human rights awareness and plans to action on a global scale that did not exist earlier. This would determine the creation of UN directed supranational tribunals specifically designed to deal with the atrocities committed in both countries, which were important precedents for the implementation of universal jurisdiction. The Latin American transitions were influenced by this new international climate to re-open the past and demand justice. In this context, the question arises: Did these events affect the way of dealing 
with the past in Spain, and how? Or did it all come too late in the Spanish case?

\section{Judge Garzón and the globalization of justice}

In the last years of the twentieth century a new global paradigm emerged. The end of the Cold War era opened the possibility of establishing international jurisdiction, a concept that appeared after WWII but had been dormant since the Nuremberg trials. Several elements came together unexpectedly: The fact that there was a certain vacuum in the international enforcement of human rights violations, and the particularity of the Spanish legal system which grants investigative powers to judges, and a 'universal jurisdiction' statute that allows 'crimes against humanity' to be tried in Spanish courts independent of where they took place (which was changed in 2009, now only admitting cases when Spanish citizens are involved). The international climate, and the uniqueness of the Spanish legal system, made Spain one of the few places where human rights crimes committed anywhere in the world could be heard in a court of law, which explains the emergence in the international arena of the figure of Baltasar Garzón, the well-known Judge from Spain's High Court, specialized in high-profile cases of national and international magnitude. That and, of course, the relentless drive and personality of the Spanish magistrate.

Judge Garzón remains a highly controversial figure at home, while widely recognized as a champion of the fight for human rights around the world, and a major proponent of the concept of 'universal jurisdiction'. ${ }^{26}$ His judicial crusades against organized crime, terrorism, drug trafficking, state crimes, and in favour of victims of political violence and the rights of indigenous peoples, have been widely recognized. Also well known is his involvement in the establishment of legal grounds for the trial of crimes against humanity in Latin America, particularly in Argentina, Chile, Uruguay, Peru and Guatemala.

Judge Garzón's international standing and reputation as a human rights crusader gained greater prominence and visibility with the 1998 indictment against ex-dictator Augusto Pinochet. Indeed, a historical precedent was set when Garzón requested Pinochet's extradition to Spain to stand trial for human rights abuses, during a medical visit in the UK. The House of Lords admitted the request, based on the principle of international jurisdiction, and he remained under arrest for 16 months. The case received wide coverage across the world as a first test of the transnational application of universal principles of crimes against humanity to one of its most notorious figures, generally considered untouchable. Human rights organizations, victim associations, and the political left in Chile, as throughout Latin America and many other parts of the world, celebrated the extradition. ${ }^{27}$ Conservative 
sectors were generally displeased, the Chilean government was embarrassed, and so was the Spanish one, led by conservative leader José María Aznar, who thought the case could affect Spanish economic interests in Latin America. Although eventually the case was dismissed for 'medical reasons', it is generally acknowledged that it represented a major step forward in the implementation of the concept of universal jurisdiction and the efforts to fight cases against human rights violations worldwide. Dictators were not immune to prosecution, national amnesty decrees did not protect with impunity those who committed crimes against humanity, and human rights principles of international jurisdiction could be implemented transnationally.

The effects of Garzón's indictment of Pinochet, legally and symbolically, directly and indirectly, cannot be underestimated. It gave renewed impetus to HROs and the efforts to undertake accountability processes in Latin America, enabling the re-opening of stalled investigations and trials, and served as precedent for many new cases that were filed in Spain and other countries. ${ }^{28}$ Culminating in prosecution efforts against Argentina's human rights violations, on April 2005, Spain's High Court condemned Argentinean Junta leader Adolfo Scilingo to a 640-year prison sentence. And, yet, in spite of these accountability measures, neither Chile nor Argentina fell apart.

In addition, the process offered the opportunity to prosecutors, HROs, NGOs, victim and civil associations across geopolitical borders, to learn from each other's successes and failures and to influence or supplement institutional measures. As Roht-Arriaza has commented, "[t]he transnationalization of human rights activist networks, and the flow of knowledge through those networks, have allowed different countries to learn from one another' ${ }^{29}$ The currents of globalization can be instrumentalized by progressive forces and affect the political elites, as Assmann and Conrad have stated: '[T]he values of counter-globalization have invaded the hegemonic memory constructs of the nation-state and they have reasserted claims to moral comport and accountability'. ${ }^{30}$ Peripheral counter-memories have thus come to occupy a central position in national and international political debates and social processes.

These types of international and transnational experiences with accountability processes have also proved valuable for reparation measures, and the establishment of truth commissions. The Chilean model of dealing with the past was created in large measure from the lessons of its neighbours, going beyond Uruguay (who did relatively little) but falling short of Argentina (who did a lot more, but the process backfired). This experience in turn influenced the transition process in South Africa, with some modifications (including public hearings and reports, and no amnesty law passed).

As the study of these 'global frames' of memory indicate, a complex network of national and transnational groups, civic and institutional 
organizations, have been instrumental in the establishing of basic principles of universal jurisdiction. Supranational institutions (such as the UN, the UE or the OAS) have generated human rights ordinances and treaties that create obligations for individual signatory countries, and these provisions have been used in court in individual countries. The UK and Chile had signed the Anti-Torture Treaty in 1988, and therefore the Pinochet case was accepted for torture crimes committed after that date. Recent international law ruled that crimes of forced kidnapping and disappearance are considered on-going violations committed in the present for as long as the victim remains disappeared, which in essence annuls the statue of limitations and opens the door for the prosecution of many human rights violations. ${ }^{31}$ The Inter-American Commission on Human Rights (IACHR) determined that amnesties in Chile, Uruguay, Argentina and El Salvador violate the principles of ACHR, and these allegations have been employed as judicial argumentation to reinitiate investigations. Similar cases have occurred in reference to other international provisions, with mixed results (some have produced confirmed sentences, but many have been thrown out of court).

\section{And the boomerang returns home . . .}

Several paradoxical ironies and asymmetries emerge from this narrative. While a Spanish judge was able to bring to trial criminals accused of crimes against humanity committed beyond the national borders, the war crimes, atrocities, tortures, mass executions, political persecution that occurred during the Civil War and the dictatorship on Spanish soil remained unexamined. There is something fundamentally odd in the picture of Spanish courts pursuing human right abuses committed by foreign dictators, while they have been unable to investigate the much larger number of atrocities committed in their own land. This realization has not escaped the attention of many intellectuals, writers, journalists and cultural critics in Spain who have been relentlessly demanding the 'recovery of historical memory'. ${ }^{32}$

It was at the turn of the millennium, during the conservative government of the Partido Popular (1996-2004), that grassroots community associations, non-governmental groups, and activists emerged with great force demanding a solution to this 'crisis of memory' in Spain. Different sectors of Spanish society mobilized around the common goal of unearthing the past, which had literally been buried under Franco's regime and symbolically reburied during the Transition. Because of the government's lack of interest in pursuing investigations, the work relied on the efforts of civic associations, NGOs, and leftist political organizations, such as Izquierda Unida. Community groups and family of victim associations started forming with the idea of reclaiming the identification of victims of Franco's repression and the recovery of the remains of their family members, disappeared and buried 
in unnamed mass graves across the land. These groups largely followed the example of grassroots movements and civic associations in Latin America on the margins of traditional power structures (the Mothers of Plaza de Mayo, in particular).

The creation in 2000 of the Asociación para la recuperación de la memoria histórica $(A R M H)$, the Association for the Recovery of Historical Memory, was followed by a myriad of other civic associations across the land, many organized within the Federación de foros por la Memoria (Federation of Forums for Memory), which have placed memory back in the centre of Spanish political life in recent years. Their claims struck a chord with Spanish society, slowly waking up to the reality of a brutal past of repression, which had been itself repressed. The ARMH website logo captures the emotional side of repressed collective memories: 'Why did the fathers of the Constitution leave my grandfather in a ditch?'33 Thousands of unmarked burial sites in ditches along the roads still remain in the Spanish landscape, invisible but ever present, just like ghosts still awaiting their day of justice. The liminal and invisible position is an adequate metaphor of their non-existing status in the margins of the official history. Internationally the best known of those victims still disappeared is the mythical figure of Federico García Lorca, a symbolic martyr of the Spanish fascist uprising, assassinated in the first weeks of the Civil War and still unaccounted for. Like a ghost, Lorca's shadow is a powerful reminder of the unsettled nature of the past and historical memory, still waiting recovery, resolution, and reparation.

In addition to these efforts, new investigations undertaken after the opening of official military archives to historians and documentarians revealed the existence of large numbers of concentration camps, where atrocities were committed on a large scale with absolute impunity. Several best-selling historical novels published in recent years such as Manuel Rivas's The Carpenter's Pencil, Javier Cercas's Soldiers of Salamis, Dulce Chacón's The Sleeping Voice and Jesús Ferrero's The Thirteen Roses, all of which have been adapted to the big screen, have given depth of emotion and further explored the extent of political crimes during the war and its aftermath for large audiences. ${ }^{34}$

This multiplicity of events lead to the new Socialist Government which came to power in 2004 to establish a special Interministerial Commission for the Study of the Situation of Civil War Victims (Comisión Interministerial para el Estudio de la Situación de las Víctimas de la Guerra Civil), presided over by the Deputy Prime Minister, in the spirit of the Investigative Commissions that had been formed in many Latin American countries earlier. The Spanish parliament declared 2006 as the 'Year of Memory', and subsequently passed in 2007 the 'Law of Historical Memory'. This highly 
contested law, insufficient for some on the left, unnecessary for many on the right, officially declared illegitimate and radically unjust the legal practices and acts of violence used by Franco's regime against its political enemies. It gave reparations to the victims of political persecution and their families, and eliminated the presence of political symbols and street names associated with Franco and his regime in all public places. It also banned pro-Franco political rallies at the Valley of the Fallen, where Falange supporters have usually gathered around Franco's tomb. It was also the expressed mandate of the Law that local courts would assist with and facilitate the recovery and identification of disappeared victims of the repression, among other provisions. Although late, and imperfect for some, the new law was a major victory for the families of the victims.

We are now coming back full circle to the beginning. Several associations of victims filed a suit requiring a full investigation into several mass graves with victims of Franco's political violence. In September 2008, Judge Garzón started preliminary general investigations of all the disappearances occurred during the Spanish Civil War and post-war dictatorship, reaching an estimate of 114,000 victims. In October 2008, he assumed the investigation of forced disappearances and mass executions, in what would be known as 'the case against the crimes of Francoism'. He ordered the excavation of 19 mass graves, including two highly symbolic ones: one, in the Valley of the Fallen, Franco's own mausoleum where thousands of unknown Republican soldiers were buried, and one in Granada, where García Lorca remains were thought to lie. Garzón requested the death certificates of the alleged perpetrators in a move that was seen by many as trying to determine responsibilities. The investigative process was initiated, and mass graves were dug, with the Partido Popular vociferously opposed to the 'reopening the wounds of the past', and the strong opposition of conservative sectors of the media, judicial bodies and the Catholic Church. The investigations and excavations were interrupted when the prosecutor's office and the Criminal Branch of the National High Court, with a conservative majority, decreed that Garzón did not have jurisdiction on the matter and the investigations were forced to stop. A month later, Garzón recused himself from the case, and let the local courts proceed with the investigations. Since then, local courts and governments, particularly those where the Partido Popular is in power, have been passive-resistant to the efforts in the recovery of victim remains, so it has been again up to the civic associations to do the job on their own, with subsidies provided by the state government from provisions under the Law of Historical Memory. The digging up of mass graves has continued across the national landscape, 2000 mass burial sites have been located so far, and more than 3000 individual victims identified and properly buried, thus bringing at last some form of closure to many. 
But that's not quite the end. Three far right political groups associated with the old regime, including the Falange, the Spanish fascist party, filed a suit against Garzón for 'prevaricación' (lack of jurisdiction), based on a technicality, the discrete competence of lower courts versus the national High Court, and the existence of the 1977 amnesty law. A variety of long time political and personal vendettas against Garzón, including rivalries with far-right judges, did the rest, with the result that the Spanish General Council of the Judiciary suspended Garzón from court on May 14, 2010, after his indictment for lack of jurisdiction. The judge subsequently requested a leave from the court and accepted a special consultant position at the International Crime Court in The Hague, the highest tribunal established on the premises of universal jurisdiction. For Emilio Silva, the president of ARMH, this move has the symbolism of a political refugee seeking asylum away from his homeland, and he has described Garzón as 'the last of Franco's exiles'. ${ }^{35}$

The case against Garzón made the headlines of news media around the world, just like many of the cases he had overseen had done before. Massive demonstrations in Spain, and international shows of support followed. One Catalan collective issued a manifesto of support precisely entitled 'For a Memory Without Borders', which has been signed by thousands around the world. The darkly ironic paradoxes surrounding this case have not gone unnoticed. While his work has been applauded by international observers, politicians, human rights activists and the world media at large, at home he has been vilified and been the target of continued attacks in what, for some, has been the most shameful act of recent Spanish history. For many, at home and abroad, it was more than just the chastising of one individual judge, but a collective slap in the face of all the victims. As one devastated family member of a victim said upon hearing the indictment, 'it feels as if they have won the war all over again' ${ }^{36}$ For most, is it incomprehensible that the judge who listened to and facilitated the demands of many seeking truth and justice for their disappeared family members, would find himself sitting in the bench of the accused, on account of a suit filed by the Spanish Fascist party directly responsible for the largest number of atrocities committed during and after the war. Human Rights Watch representative Reed Brody denounced the 'double standard' of Spanish justice system, which investigated the Argentinean and Chilean dictatorships, but indicted a Spanish judge for doing the same with the Spanish dictatorship. ${ }^{37}$ In another boomerang effect, a group of Galician immigrants from Argentina filed a suit in Buenos Aires to re-open the case against the human rights violations of the Franco regime. Nora Cortiñas, a member of the Madres de la Plaza de Mayo, noted the symbolic implications of this case, as a way of repaying Spain in kind for the earlier opening of investigations about the desaparecidos in Argentina in Spanish courts. ${ }^{38}$ 
The Garzón case has ultimately meant the return of the repressed with full force, the haunting of the ghosts of the past improperly buried, and has confirmed the unfinished business of the Spanish Transition, especially when seen in contrast with all the transnational efforts to promote historical memory, human rights, and backward looking accountability around the world. In a certain way, it was fitting that Garzón's own case would become the centre of international attention, and a precedent-seeking trial, as many see it as the ultimate test of universal jurisdiction in the fight against human rights abuses. Peruvian lawyer Roland Gamarra, who successfully prosecuted former Peruvian president Roberto Fujimori for authorizing a civilian massacre that killed 15 people, in spite of an amnesty law, has acknowledged that the case 'is transcendent for those of us fighting against impunity, and is more relevant still because the accused is an iconic magistrate'. ${ }^{39}$ Gamarra will participate in the trial as a witness to the fact

that a current of legal interpretation exists, based on the expansion of International Criminal Law, which favours the persecution of those crimes committed in the context of crimes against humanity, despite the time passed since they were perpetrated and above the so-called laws of pardon ... The international laws protect judge Garzón to investigate the crimes of the Franco era. ${ }^{40}$

Garzón himself has recognized the global implications and the opportunity that his own trial would put those theories to the test:

The defence that my attorney proposes to develop will be based on the fact that the decisions I took are protected by the rules of International Criminal Law commonly accepted by civilised nations and collected in the various treaties Spain has signed. . . . They are the rules that require us to give protection at all times to the victims of forced disappearance, that consider crimes against humanity unpardonable, and that proscribe the laws of pardon to the extent that they impede persecution of crimes against humanity or genocide..$^{41}$

The UN Human Rights Committee has criticized Spain for having such high number of still unidentified victims illegally buried in mass graves, and has stated that crimes against humanity such as the ones Garzón was trying to investigate are not subject to criminal prescription and therefore cannot be subject to amnesty nor pardon. These arguments have been presented by international jurists, academics, and human rights defendants across the world in an open letter to the Spanish Supreme Court, but their eventual effect still remains unknown. ${ }^{42}$

Ultimately, Garzón's quixotic quest for reparation of injustices and crimes against humanity around the globe illustrates the possibilities raised, as well as the challenges presented, towards the goal of universal jurisdiction and 
the eradication of impunity by the competing forces of individual nationstates, transnational grassroots networks, and supranational organizations in the new global dynamics. But it also suggests the existence of networks of memory without borders, and the potential of those memories to make an impact on the global stage and change the future. As former Director General of UNESCO Federico Mayor Zaragoza has written:

The truth of exactly what happened must be revealed, without limitations. ... Only through this collective memory, with a profound knowledge of the past, will we be capable of building the appropriate future for our common destiny. ... And we can only do so with memories without borders, with justice without borders. ${ }^{43}$

1 Andreas Huyssen, 'Present Pasts: Media, Politics, Amnesia', Public Culture (PC), 12, 1 (2000), pp.21-38, quote at p.28.

2 Aleida Assmann and Sebastian Conrad, eds, Memory in a Global Age. Discourses, Practices and Trajectories, Basingstoke, 2010, p.1.

3 See for example Carlos H. Waisman, 'Latin American Transitions in the Spanish Mirror', in Carlos H. Waisman and Raanan Rein, eds, Spanish and Latin American Transitions to Democracy, Brighton, 2005, pp.1-15.

4 Donald Share, 'Transition to Democracy and Transition through Transaction', Comparative Political Studies (CPS), 19, 4 (1987), pp.525-48. Political elites, in this context, include both those holding political power in government, and the leadership of the main oppositional forces.

5 Although some scholars prefer to describe it as a process of negotiated rupture, since there are both elements of continuity (political process conducted within the legality of the old regime, including the restoration of the monarchy) and rupture (ultimate dismantling of the political structure of Francoism). See Carsten Humlebaek, 'Creating a New Cohesive National Discourse in Spain after Franco', in Luis Martin-Estudillo and Roberto Ampuero, eds, Post-Authoritarian Cultures. Spain and Latin America's Southern Cone, Nashville, 2008, pp.196-217.

6 The Spanish Pavilion at the 2010 World Expo in Shanghai celebrates spectacularly the narrative of Spanish modernization as a result of the Transition, considered 'el gran éxito de España' ['Spain's great success'] by the Spanish commissioner María Tena. See José Reinoso, 'La paella pasada al gusto chino', El País, 30 August 2010, http://www.elpais .com/articulo/revista/agosto/paella/pasada/gusto/chino/elpten/20100830elpepirdv_1/Tes.

7 'La Transición' (the Transition) has become a grand narrative in Lyotard's sense (JeanFrançois Lyotard, The Postmodern Condition: A Report on Knowledge, Manchester, 1984). Cultural critics have recently questioned the unexamined assumption of the Spanish Transition as a 'model' referring to its lack of closure in dealing with the past as well as its symbolic deficit. See Luis Martín-Estudillo and Roberto Ampuero, eds, Post-Authoritarian Cultures. Spain and Latin America's Southern Cone. Nashville, 2008.

8 For a discussion of these issues, see Gregorio Morán, El precio de la transición, Barcelona, 1991; Alberto Medina Domínguez, Exorcismos de la memoria. Políticas y poéticas de la melancolía en la España de la transición, Madrid, 2001; José F. Colmeiro, 


\section{Journal of New Zealand Studies}

Memoria histórica e identidad cultural: De la postguerra a la postmodernidad, Barcelona, 2005; and Jo Labanyi, 'Memory and Modernity in Democratic Spain: The Difficulty of Coming to Terms with the Spanish Civil War', Poetics Today (PT), 28, 1 (2007), pp.89-116.

9 Mario Benedetti, El olvido está lleno de memoria, Madrid, 1995.

10 The list would include well-known contemporary Spanish writers such as Manuel Vázquez Montalbán, Carmen Martín Gaite, Juan Marsé, Jorge Semprún, Manuel Leguineche, Jesús Torbado, Montserrat Roig, Fernando Fernán Gómez, and film directors such as Basilio Martín Patino, Jaime Chavarri, and Jaume Camino, among many others. See Fabrizio Cossalter, 'Las raíces del desencanto. Notas sobre la memoria literaria de la Transición', in Enric Bou and Elide Pittarello, eds, (En)claves de la Transición. Una visión de los Novísimos. Prosa, Poesía, Ensayo, Madrid, 2009, pp.39-56.

11 Paloma Aguilar, 'Justice, Politics and Memory in the Spanish Transition', in Alexandra Barahona De Brito, Carmen González Enríquez and Paloma Aguilar, eds, The Politics of Memory and Democratization, Oxford, 2001, pp.92-118.

12 Gutmaro Gómez Bravo, 'La amenaza de la violencia: conflicto y violencia en la transición', in Gutmaro Gómez Bravo, ed, Conflicto y consenso en la transición española, Madrid, 2009, pp.7-20.

13 This would be a case of 'retrospective fallacy'. See Aguilar, p.97.

14 The concept of a political 'transition' from the dictatorship was in the vocabulary of the opposition as early as 1939 (See Santos Juliá, “"Transición” antes de la Transición', in Gutmaro Gómez Bravo, ed., Conflicto y consenso en la transición española, Madrid, 2009, pp.21-38. Since the 1960s a politics of national reconciliation was the new main goal for the Spanish Communist Party, the leader organization of the anti-Franco opposition in exile, as well as a "general amnesty" for both sides. The first unitary assembly of all main anti-Franco oppositional forces that took place in Munich in 1962 did not produce any demands for retributive justice or accountability measures (see Aguilar, p.98).

15 Aguilar, p.102.

16 ‘Amnistía al fin', El País, 15 October 1977, p.6.

17 Félix Moral, Veinticinco años después. La memoria del franquismo y de la transición a la democracia en los españoles del año 2000, Madrid, 2001.

18 Marianne Hirsch, Family Frames: Photography, Narrative, and Postmemory. Cambridge, 1977.

19 Aguilar also mentions 'the overwhelming desire of Spanish society to see a peaceful and gradual change and even to pretend that it had forgotten the past rather than call anyone to account' (Aguilar, p.99).

20 For a more detailed discussion of the role of memory and the performative aspect of the Movida, see my article, 'Plumas y pistolas: La crisis constitucional del 23-F y la memoria histérica de Eduardo Mendicutti’ Revista de Estudios Hispánicos (REH), 44 (2010), pp.589-609.

21 See Charles Powell, 'La transición española vista desde Washington', in Gutmaro Gómez Bravo, ed, Conflicto y consenso en la transición española, Editorial Pablo Iglesias, Madrid, 2009, pp.197-255.

22 Quoted in Natalia Junquera, 'Almodóvar se encierra por Garzón', EL PAÍS, 13 April. Web http://www.elpais.com/articulo/espana/Almodovar/encierra/Garzon/elpepuesp /20100413elpepunac_27/Tes. 
23 This issue was explored in films such as Carlos Saura's Los ojos vendados, or more recently Almodóvar's All about my Mother, featuring in the main role Cecilia Roth, in fact an Argentinean exiled in Spain in 1976. Some of the better known Southern Cone intellectuals exiled in Spain in the years of the transition included Luisa Valenzuela, Blas Matamoro, Juan Gelman or Mario Benedetti.

24 Arguably, the first cause célèbre 'desaparecido' was the exiled Basque writer and diplomat Jesús de Galíndez, who was kidnapped by agents of Dominican dictator Rafael Leónidas Trujillo in New York in 1956. The 'Galíndez case' was officially investigated by a commission of the US Congress and the FBI and the ramifications of the case would be the catalyst for the eventual fall of the Trujillo dictatorship.

25 See Heinrich Sassenfeld, 'Some Notes on the International Influences on Transition Processes in the Southern Cone', in Luis Martín-Estudillo and Roberto Ampuero, eds, Post-Authoritarian Cultures. Spain and Latin America's Southern Cone, Nashville, 2008, pp. 233-48.

26 Judge Garzón came to prominence in the early 1990s, with the spectacular success of his judicial investigations on drug trafficking, in particular the infamous Galician-Colombian connection (Nécora Operation), and against Basque terrorism, and his involvement with other high profile cases (such as money laundering and arms smuggling) would regularly capture newspapers front pages. His celebrity status and clean image helped the corruption-laden Socialist party win the Spanish general elections in 1993, where he was listed as an independent directly under Felipe González. He resigned a few months later due to differences with other high ranking socialists and allegedly not receiving the cabinet post he expected. He then launched a furious operation against internal government corruption, the illegal practices of state terror and the infamous GAL secret operation. As a result of his high profile activities, Garzón is quite controversial in Spain: at the same time that he is widely recognized as a champion of truth, justice and a fighter against corruption and terrorism, his progressive but independent and uncompromising spirit has made him the target of ire from individuals and organizations affected by his actions across the political spectrum, far right to far left, and everything in between. He fought against Basque terrorist organizations, their social and media outlets, as well as against the illegal dirty war against Basque terrorism. He ordered the imprisonment of the Socialist former Minister of the Interior José Barrionuevo, for his responsibilities in state counter-terror violence. The Conservative Partido Popular party has also been the subject of Garzón's multiple investigations into corruption charges.

27 While gaining admiration from many, a cloud of 'colonialism' and interference on national affairs was cast by conservative Chilean sectors who wanted to protect its sovereignty.

28 The Chilean Supreme Court decided on two occasions that Pinochet's self-imposed immunity status did not prevented him from being charged with human rights violations. The defense's argument based on his senility ultimately prevailed.

29 Naomi Roht-Arriaza, 'The Role of International Actors in National Accountability Processes', in Alexandra Barahona De Brito, Carmen González Enríquez and Paloma Aguilar, eds, The Politics of Memory and Democratization, Oxford, 2001, pp.40-64, quote at p. 40

30 Assmann and Conrad, Memory, p.2.

31 Gustavo A. Remedi, 'Tejanos: The Uruguayan Transition Beyond', in Luis Martín-Estudillo and Roberto Ampuero, eds, Post-Authoritarian Cultures. Spain and Latin America's Southern Cone, Nashville, 2008, pp.99-121, quote at p.114. 


\section{Journal of New Zealand Studies}

32 The realization of this crisis of memory led former Spanish Prime Minister and former leader of the anti-Franco opposition, Felipe González, to lament retroactively in 2001 that he felt a certain personal responsibility for the collective loss of historical memory. He confessed to feeling 'responsible for not having caused a debate on our historical past, the Franco period and the Civil War (. . . thus) responsible for a part of the loss of our historical memory' (quoted in Humlebaek, p.208).

33 The Internet has proven instrumental for these organizations in the diffusion of their message and coordination efforts. See http://www.memoriahistorica.org, and http://www .foroporlamemoria.info.

34 The transnational memory of the Spanish civil war has also been represented in Ken Loach's Land and Freedom and Guillermo del Toro's The Devil's Backbone and his multiple Academy award winner Pan's Labyrinth.

35 Natalia Junquera, 'Silva: 'Garzón es el último exiliado del franquismo', El País, 12 May 2010, Web http://www.elpais.com/articulo/espana/Silva/Garzon/ultimo/exiliado /franquismo/elpepunac/20100512elpepinac_4/Tes.

36 Pedro Almodóvar also echoed that feeling at the solidarity sit-in at Madrid's Universidad Complutense: 'If Falange is able to put Garzón in the dock it would be as if Franco had won all over again, and that would be very difficult to swallow', Natalia Junquera, 'Almodóvar se encierra por Garzón', EL PAÍS, 13 April 2010, Web http://www.elpais.com /articulo/espana/Almodovar/encierra/Garzon/elpepuesp/20100413elpepunac_27/Tes. Following Garzón's endictment, Almodovar's own production company released Azucena Rodríguez's short documentary Contra la impunidad [Against Impunity] where different high profile Spanish artists and writers, including Almodóvar, represent in front of the camera the stories of disappeared victims under Franco.

37 'Miles de personas se manifiestan "contra la impunidad del franquismo y en apoyo a Garzón”, RTVE, 24 April 2010, Web http://www.rtve.es/noticias/20100424/miles -personas-se-manifiestan-contra-impunidad-del-franquismo-apoyo-a-garzon/328876 .shtml.

38 J.L. Estévez, 'Un grupo de gallegos se querella contra el franquismo en Argentina', EL PAÍS, 1 May 2010. Web http://www.elpais.com/articulo/Galicia/grupo/gallegos/querella /franquismo/Argentina/elpepiautgal/20100501elpgal_6/Tes.

39 Ángel Páez, 'Peru's Past to Serve as Evidence in Spanish Judge's Trial', IPS NEWS, 2 July 2010, Web http://ipsnews.net/news.asp?idnews=52037. Gamarra has spent several years representing victims of the state-led repression during Peru's internal conflict. He was head of the Human Rights Unit at the Ad Hoc Prosecution Office created in 2000 to investigate charges against Fujimori and his intelligence advisor, fellow convict Vladimiro Montesinos.

40 Ibid.

41 Ibid.

42 'Open Letter to the Spanish Judiciary Authorities in Solidarity with Justice Baltasar Garzón', International Federation for Human Rights, 23 March 2010, Web http://www .fidh.org/Open-letter-to-Spanish-judiciary-authorities-in.

43 Federico Mayor Zaragoza, 'Memories Without Borders. Justice Without Borders', Blogspot, 20 May 2010, Web http://federicomayor-eng.blogspot.com/2010/05/memory-without -borders-justice-without.html. 